\title{
ANALISIS PERSEDIAAN KOPI DALAM MEMENUHI PERMINTAAN PASAR \\ (Studi kasus di Kelompok Tani Rahayu \\ Kecamatan Pangalengan Kabupaten Bandung )
}

A coffee supply analysis in fullfiling of market demands ( a case study in the

“Kelompok Tani Rahayu” Kecamatan pangalengan, Kabupaten Bandung ).

\author{
Wini Fetia Wardhiani \\ Jurusan Agribisnis Fakultas Pertanian Universitas Bale Bandung \\ Wini_fetia@yahoo.com
}

\begin{abstract}
An analysis of the coffee supply to meet market demand, a case study in the "Farmers Rahayu" Pangalengan, Bandung regency. Rahayu Farmer Group is one of the most advanced coffee producer compared with other farmer groups in the village Margamulya. However, Rahayu Farmer Group have yet to implement a particular supply model for managing a supply of coffee. Thus, Farmers Group Rahayu not know how efficient and effective inventory management coffee they have done. Therefore, the authors feel compelled to discuss more about the study of coffee in the inventory management Rahayu Farmer Group. The purpose of this research is to know about the inventory management is done by Farmers Group Rahayu and coffee inventory management according to the model of EOQ (Economic Order Quantity). Model Research conducted in this study is a case study. Data collection techniques used were observation, interview, and literature study.The results prove that inventory management is done by Farmers Group Rahayu has not been effective and efficient. This can be evidenced through a comparison between the inventory model used by the actual conditions that occur in the company. EOQ inventory model has a total cost of $17.43 \%$ lower. EOQ model with safety stock have 5\% lower total cost of supply.
\end{abstract}

Keywords: Coffee. Inventories, Expired, EOQ

\section{PENDAHULUAN}

Indonesia merupakan salah satu Negara dengan jumlah produksi kopi terbesar keempat setelah Brazil, Vietnam dan Colombia yang menguasai pangsa pasar kopi dunia, Indonesia merupakan urutan keempat penghasil kopi di dunia.

Tanaman kopi merupakan salah satu komoditas unggulan keempat dari Sembilan jenis komoditas unggulan yang dikelola oleh Dinas Perkebunan Provinsi Jawa Barat.Meskipun Jawa Barat belum termasuk sepuluh besar produsen kopi di Indonesia namun pemerintah Provinsi Jawa Barat terus berusaha meningkatkan produksi kopi yang ada di Jawa Barat caranya dengan terus membina Kelompok Tani kopi yang ada di Jawa Barat agar dapat lebih meningkatkan produksinya. 
Sebagian besar budidaya tanaman kopi yang dilakukan di Jawa Barat diusahakan pada perkebunan rakyat.Kabupaten Bandung merupakan salah satu wilayah yang memiliki areal perkebunan kopi terluas dibandingkan dengan 17 daerah perkebunan kopi lainnya di Jawa Barat.Luas areal perkebunan kopi rakyat di Kabupaten Bandung mencapai 8.469 hektar dan sebanyak 5.093 hektar lahan perkebunan kopi telah digunakan untuk melakukan usahatani kopi. Berdasarkan data dari Dinas Pertanian dan Perkebunan Kabupaten Bandung, salah satu sentra produksi kopi di Kabupaten Bandung adalah kecamatan Pangalengan yang tersebar di tujuh desa. Desa Margamulya merupakan salah satu desa dengan jumlah produksi kopi terbesar dengan jumlah tanaman yang sudah menghasilkan cukup tinggi dibandingkan dengan desa-desa lainnya.'

Tanaman kopi yang dibudidayakan di desa Margamulya merupakan kopi jenis arabika.Hal tersebut didorong oleh kondisi geografis Desa Margamulya yang berada pada ketinggian $1200 \mathrm{~m}$ dari permukaan laut dimana dengan ketinggian tersebut sudah memenuhi kriteria untuk dibudidayakannya komoditas kopi dengan jenis arabika. Hampir sebagian besar areal perkebunan kopi yang ada di Desa Margamulya dikelola oleh para petani yang memiliki luas lahan tidak terlalu besar sehingga perkebunan kopi ini dikenal dengan istilah perkebunan kopi rakyat, yaitu perkebunan yang dikelola oleh para petani rakyat dengan luasan kurang dari 0,5 hektar.
Untuk itu dirasa perlu adanya manajemen persediaan yang memadai dalam memenuhi permintaan pasar mengingat tidak terlalu luasnya perkebunan yang dikelola para petani rakyat ini, sedangkan di saat-saat tertentu pemintaan akan kopi meningkat. Jika manajemen persediaan telah dipersiapkan sebelumnya Kelompokkelompok Tani tersebut tidak akan kekurangan persediaan kapanpun permintaan pasar meningkat.

Salah satu upaya untuk menumbuhkan kemampuan petani dalam mengelola usahataninya adalah melalui sebuah lembaga atau kelompok yang mewadahi pembangunan masyarakat tani tersebut.Kelompok dalam hal ini berperan sebagai kelas belajar, sebagai unit produksi dan sebagai wahana kerjasama antar anggota kelompok. Para petani kopi di Desa Margamulya tergabung dalam kelompok tani dengan nama Kelompok Tani Rahayu. Kelompok Tani Rahayu pada awalnya merupakan sebuah kelompok tani dengan komoditas usahataninya sayuran. Namun, sejak tahun 2006 kelompok tani ini berubah nama menjadi Kelompok Tani Hutan. Kelompok Tani Rahayu dalam melakukan usahatani perkebunan kopinya sudah mengalami kemajuan dibandingkan dengan Kelompok Tani lainnya yang berada di Desa Margamulya.Hal tersebut didorong oleh sudah tersedianya sebuah mesin khusus untuk dilakukan pengolahan kopi dimana kepemilikannya berada dalam pengelolaan kelompok. 
Keberadaan sebuah kelompok tani memiliki peranan yang cukup penting dalam membentuk perubahan perilaku anggota dan menjalin kemampuan dalam bekerjasama antar sesama anggota kelompok. Dengan terbentuknya sebuah kelompok tani, akan mempermudah dalam menyampaikan program dan tujuan yang ingin dicapai oleh kelompok tani tersebut. Kelompok tani yang telah terbentuk diharapkan dapat dijadikan sebagai wadah bagi para petani dalam meningkatkan kemampuan petani dengan atau tanpa adanya intervensi dari luar sehingga dapat mengembangkan usaha perkebunan para anggota kelompoknya yang akan timbul dari sebuah kedinamisan kelompok. Selain itu, dengan adanya KTH maka akan berdampak positif terhadap ekosistem hutan tersebut. Para anggota kelompok disamping melakukan aktivitas usahataninya secara tidak langsung juga turut menjaga kelestarian hutan sekitar dan ekosistem yang ada di dalamnya.

Secara umum, terdapat dua jenis biji kopi, yaitu arabika (kualitas terbaik) dan robusta. Sejarah mencatat bahwa penemuan kopi sebagai minuman berkhasiat dan berenergi pertama kali ditemukan oleh Bangsa Etiopia di benua Afrika sekitar 3000 tahun (1000 SM) yang lalu. Kopi kemudian terus berkembang hingga saat ini menjadi salah satu minuman paling populer di dunia yang dikonsumsi oleh berbagai kalangan masyarakat. Indonesia sendiri telah mampu memproduksi lebih dari 400 ribu ton kopi per tahunnya. Di samping rasa dan aromanya yang menarik, kopi juga dapat menurunkan risiko terkena penyakit kanker, diabetes, batu empedu, dan berbagai penyakit jantung. Konsep keunggulan bersaing saat ini adalah kemampuan perusahaan untuk menyerahkan barang dan jasa pada waktu dan tempat yang diinginkan oleh pelanggan, dalam pasar domestik maupun pasar internasional, pada harga yang terbaik dibandingkan dengan perusahaan lain. Dalam menghasilkan barang dan jasa perusahaan tersebut menggunakan biaya dan sumberdaya yang paling efisien.

Pemasaran kopi dari kelompok tani Rahayu ini yaitu ke PT NUGA, yang kemudian dari PT Nuga disalurkan kepada café-café yang ada di kota Bandung seperti Café Ngopdoel, Café Lisung dan masih banyak lagi. Disalurkan juga langsung ke konsumen melalui counter yang ada di daerah komplek Margahayu Raya Bandung. Terakhir melalui eksportir. Kelompok Tani Rahayu selain menerima pasokan dari anggotanya juga menerima kopi dari berbagai mitra dari kelompok tani ini. Diantaranya yaitu Petani Plasma yaitu petani binaan dari kelompok tani rahayu ini,Perhutani, Petani di luar kelompok tani rahayu dan kelompok petani pimpinan bpk Dinuri.

Untuk saat ini kemitraan yang sudah terjalin sudah dapat memenuhi persediaan yang dibutuhkan kelompok tani rahayu dalam memenuhi permintaan konsumen. Namun dalam melaksanakan kegiatannya, Kelompok Tani Rahayuseringkali menghadapi lonjakan permintaan pasar yang melampaui kemampuan kelompok tani dalam memenuhi permintaan konsumen. Seringkali kelompok tani masih kekurangan dalam persediaan sehingga dibutuhkan strategi dalam memenuhi permintaan pasar tersebut. 
Berdasarkan fenomena yang telah dipaparkan sebelumnya, terdapat beberapa hal menarik untuk diteliti. Pertama, bagaimana mengelola pengadaan kopi sehingga dapat memenuhi permintaan pasar. Kedua, berkaitan dengan pengelolaan pengadaan komoditas kopi, bagaimana sistem manajemen pengadaaan kopi yang baik agar tercapai efektivitas dan efisiensi dalam kelompok tani. Ketiga, sejalan dengan tujuan manajemen yaitu tercapainya efektivitas dan efisiensi, perlu dicari model pengendalian persediaan kopi yang sebaiknya dilakukan Kelompok Tani Rahayu agar mampu memenuhi permintaan pasar. Tujuan Penelitian : Mengetahui manajemen persediaan kopi di Kelompok Tani Rahayu dalam memenuhi permintaan pasar. Dan Menganalisa efektifitas dan efisiensi pengelolaan persediaan kopi pada Kelompok Tani Rahayu

\section{METODOLOGI PENELITIAN}

\section{Desain Penelitian}

Desain penelitian yang digunakan adalah desain kualitatif dengan maksud untuk mengkaji secara mendalam dan memperoleh gambaran mengenai analisis persediaan Kopi dalam memenuhi permintaan pasar di Kelompok Tani Rahayu. Teknik penelitian yang dilakukan adalah studi kasus yaitu dengan melakukan penyelidikan mendalam mengenai subjek tertentu. Menurut Vredenbregt (1987), studi kasus ialah suatu pendekatan yang bertujuan untuk mempertahankan keutuhan dari objek, artinya data yang dikumpulkan dalam rangka studi kasus dipelajari sebagai suatu keseluruhan yang terintegrasi.

Dari data tersebut kemudian dilakukan analisis serta membuat interpretasi yang lebih mendalam dari hubungan teori dan fakta yang diperoleh pada penelitian tersebut. Penelitian dilakukan di Kelompok Tani Rahayu mengingat saat ini di Pangalengan Kabupaten Bandung kelompok tani ini memiliki anggota yang cukup banyak dan kelompok tani ini terus melakukan pengembangan dan inovasi kelompoknya untuk memenuhi permintaan konsumen. Bahan untuk studi kasus dapat diperoleh dari sumbersumber seperti hasil pengamatan, laporan atau keterangan dari orang yang banyak tahu tentang hal tersebut.

\section{Teknik Pengumpulan Data}

Metode pengumpulan data yang digunakan dalam penelitian tersebut dilakukan secara sengaja (purposive). Responden dalam penelitian ini antara lain : Pengurus Kelompok Tani Rahayu, anggota Kelompok Tani Rahayu, pemilik café, konsumen/pelanggan café. Penentuan responden didasarkan dengan pertimbangan kompetensi dan wewenang yang dimiliki mengenai topik penelitian tersebut. 


\section{Teknik Pengolahan dan Analis is Data}

Analisis data merupakan tindakan mengolah data menjadi informasi yang bermanfaat untuk menjawab masalah penelitian. Untuk mengetahui bagaimana pengendalian persediaan kopi di Kelompok Tani Rahayu didapat dengan cara analisis deskriptif. Sementara itu analisis data dilakukan untuk mengetahui perbedaan biaya antara pengelolaan persediaan kopi yang dilakukan oleh perusahaan dengan pengelolaan persediaan oleh model EOQ yang dilihat dari segi total biaya persediaannya. Dengan demikian diperoleh metode yang paling efisen dalam penggunaan biaya. Perhitungan dengan EOQ ini dapat dilakukan dengan menggunakan persamaan sebagai berikut

$\mathrm{D}=$ Jumlah kebutuhan barang (unit/tahun) $\quad \mathrm{S}=$ Biaya pemesnan (rupiah/pesanan)

$\mathrm{h}=$ biaya penyimpanan $(\%$ terhadap nilai barang) $\quad \mathrm{C}=$ Harga barang (rupiah/unit)

$\mathrm{H}=\mathrm{h} \times \mathrm{C}=$ Biaya penyimpanan (rupiah/unit/tahun)Q $\mathrm{Q}$ Jumlah pemesanan (unit/pesanan)F $=$ Frekuensi pemesanan (kali/unit)T = Jarak waktu antar pesanan (tahun, hari)

$\mathrm{TC}=$ Total biaya persediaan (rupiah/tahun)

Biaya pemesanan pertahun $=$ frekuensi pesanan $\mathrm{x}$ biaya pesanan

$$
=\left(\frac{D}{Q} \times S\right)
$$

Biaya penyimpanan pertahun = persediaan rata-rata $\mathrm{x}$ biaya penyimpanan

$$
=\left(\frac{Q}{2} \times \mathrm{H}\right)
$$

EOQ terjadi jika biaya pemesanan = biaya penyimpanan

$$
\begin{gathered}
\left(\frac{D}{Q} \times \mathrm{S}=\frac{Q}{2} \times \mathrm{H}\right) \\
\left(2 \mathrm{DS}=\mathrm{Q}^{2} \mathrm{H}\right)
\end{gathered}
$$

$$
\left(\mathrm{Q}^{2}=\frac{2 D S}{H}\right)
$$

$$
\left(\mathrm{Q}^{*}=\sqrt{\frac{2 D S}{H}}\right)
$$

Q* adalah EOQ, yaitu jumlah pemesanan yang memberikan biaya total persediaan terendah. Sementara itu, biaya yang dikeluarkan untuk pemesanan ekonomis tersebut adalah $:\left(\mathrm{TC}=\frac{D}{Q} \times \mathrm{S}+\frac{Q}{2} \times \mathrm{H}\right)$

Frekuensi pemesanan merupakan permintaan per tahun dibagi dengan jumlah pesanan dalam satu tahun, sehingga jumlah frekuensi pesanan yang paling ekonomis adalah sebagai berikut $:\left(\mathrm{F}=\frac{D}{Q *}\right)$

Untuk mengetahui jangka waktu antar tiap pesanan digunakan perhitungan yaitu :

$$
\left(\mathrm{T}=\frac{\text { Jumlahkariker japertahun }}{\text { frekuensipesanan }}\right)
$$


Menurut Handoko (1992), teknik pengendalian persediaan dengan menggunakan EOQ harus memenuhi beberapa asumsi sebagai berikut :

1. Permintaan relatif konstan

2. Harga per unit produk relatif konstan

3. Biaya penyimpanan per unit per tahun konstan

4. Biaya pemesanan per pesanan konstan

5. Waktu tunggu (lead time) diketahui

6. Tidak terjadi kekurangan bahan (stock out)

Dalam memperoleh rasio sensitivitas adalah melalui pendekatan matematis. Dalam pendekatan ini dikenal beberapa notasi antara lain sebagai berikut :

$\mathrm{TC}=$ Total biaya tidak optimal $\mathrm{TC}^{*}=$ Total biaya optimal

$\mathrm{D}=$ Jumlah kebutuhan setahun

$\mathrm{Q}=$ Jumlah pemesanan tidak optimal

$\mathrm{Q}^{*} \quad=$ Jumlah pesanan optimal

Ss $\quad=$ Persediaan pengaman

seharusnya

$\mathrm{H}=$ Harga bahan per kilogram

$\mathrm{C}$ = Biaya penyimpanan per tahun

$\mathrm{O}$ = Biaya pemesanan

Rasio sensitivitas bahan persediaan dapat dihitung dengan rumus sebagai berikut :

Rasio sensitivitas $\frac{T C}{T C^{2}}=$ $\frac{\frac{D}{Q} \times Q+\left(\frac{Q}{2}+S S\right) \times C H}{\left(\frac{D}{Q *)} \times O+\left(\frac{Q *}{2}\right)+S S \times C H\right.}$
Sedangkan biaya marjinal adalah rasio sensitivitas yang diperoleh dikurangi rasio sensitivitas terendah (1) dikalikan dengan total biaya persediaan. Jika dibuat dalam bentuk persamaan adalah sebagai berikut :

Biaya marjinal $=($ rasio sentivitas -1$) \mathrm{x}$ total biaya persediaan

\section{HASIL DAN PEMBAHASAN Gambaran Umum Kelompok Tani Rahayu}

\section{Sejarah Kelompok Tani Rahayu}

Kelompok Tani Rahayu merupakan kelompok tani yang bergerak di bidang budidaya Hortikultura pada tanggal 24 September 1992 beranggotakan 27 orang yang di prakarsai oleh Bapak Supriatnadinuri dengan berbagai jenis tanaman hortikultura, lalu pada tanggal 17 Mei 2001 berdasarkan hasil rapat anggota dan pimpinan, Kelompok Tani Rahayu ini beralih komoditi menjadi tanaman perkebunan Kopi yang beralamat di Pasirmulya RT 05 RW 14 Desa Margamulya Kec. Pangalengan Kab. Bandung beranggotakan 7 orang. Seiring waktu berjalan dengan suka duka yang dihadapi oleh para anggota kemudian pada tahun 2011 jumlah anggota menjadi 67 orang. 
Sampai saat ini Kelompok Tani Rahayu terus berusaha meningkatkan produksi dengan cara menambah terus jumlah anggota kelompok tani dan juga menambah jumlah kelompok tani binaan. Selain itu kelompok Tani
Rahayu juga terus mengadakan pelatihan dan bimbingan secara intensif kepada Kelompok Tani binaan nya juga kepada anggota kelompok tani rahayu sendiri

\section{Alur Penjualan Kopi}

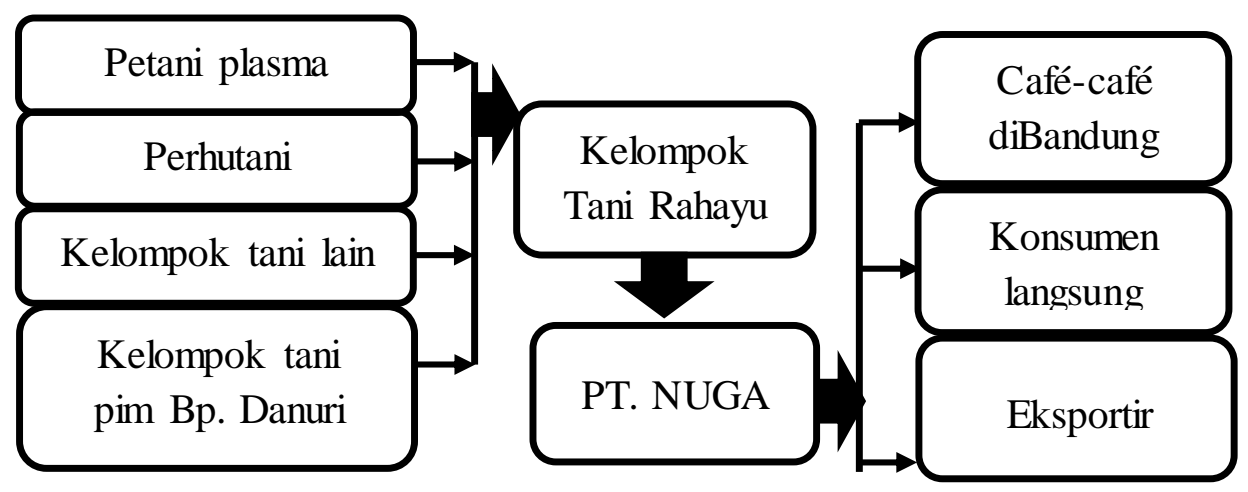

\section{Konsep Kelompok Tani Rahayu}

Produk yang dihasilkan oleh kelompok tani ini telah dipasarkan dengan cara :

$\square$ Direct selling, yaitu penjualan langsung kepada konsumen yang memang telah mengetahui kualitas kopi produk kami

$\square$ Indirect selling, yaitu penjualan produk bermitra dengan eksportir maupun retail untuk memasarkan produk kami

\section{Manajemen Persediaan Kopi yang}

Diterapkan Kelompok Tani Rahayu

1. Perencanaan dan Pengadaan Persediaan Kopi

Perencanaan persediaan kopi sebagai bahan baku pembuatan kopi bubuk instan yang diterapkan oleh Kelompok Tani Rahayu disesuaikan dengan rencana target produksi atau rencana penjualan produk. Pemesanan kopi dilakukan setiap sebulan sekali sehingga dalam satu tahun terdapat 12 kali pemesanan.Jumlah pemesanan kopi berbeda antara masa panen dengan masa tidak panen. Masa panen yaitu bulan April hingga Agustus yaitu sebanyak 1000 kilogram perbulan, sedangkan masa tidak panen yaitu bulan Sepetember hingga Maret sebanyak 250 $\mathrm{kg}$ perbulan. Jangka waktu antar tiap pemesanan adalah selama 1 hari. Jumlah permintaan kopi bubuk juga menjadi pertimbangan penting dalam penentuan kuantitas dan intensitas pemesanan kopi.

Kopi diperoleh dari petani binaan yang merupakan mitra dari Kelompok Tani Rahayu. Adapun spesifikasi kualitas kopi yang diinginkan Kelompok Tani Rahayu dari pemasok adalah Cherry merah matang, HS kadar air $40 \%$, Green bean kadar air $10 \%$ tanpa ada reject atau sudah disortir. 


\section{Metode Pemakaian dan Pe rsediaan Pengaman Kopi}

Metode pemakaian kopi yang diterapkan oleh Kelompok Tani Rahayu adalah metode FIFO (first in first out) yaitu kopi yang pertama dipakaiadalah kopi yang pertama sekali tiba di gudang penyimpanan bahan baku. Hal tersebut bertujuan untuk menghindari terjadinya kerusakan pada kopi akibat disimpan terlalu lama di gudang penyimpanan bahan baku.

Penyimpanan kopi di gudang dilakukan secara sederhana. Kopi dikemas tergantung dari jenis kopinya. Jika kopi bubuk disimpan dalam kemasan aluminium foil, roasted disimpan dalam kemasan aluminium foil dan yang terakhir greenbean disimpan dalam karung. Pemeliharaan kopi selama di gudang dengan cara menjaga suhu ruangan agar tidak lembab yaitu dengan cara menggunakan palet dan membuat sirkulasi udara yang baik.

Persediaan kopi dilakukan ketika masa panen tiba, hal tersebut dilakukan untuk mengantisipasi permintaan konsumen di saat bukan masa panen. Sejauh ini persediaan kopi yang dilakukan saat masa panen dapat memenuhi permintaan konsumen saat bukan masa panen. Pada masa panen, yaitu bulan April hingga Agustus ratarata hasil panen sebanyak 1 ton.Sedangkan di luar masa itu rata-rata hasil panen sebanyak 2 kuintal.

\section{Biaya-biaya dalam Perse diaan Kopi}

\section{Biaya Pemesanan}

Pemesanan kopi dilakukan sebanyak 12 kali pada tahun 2012. Pemesanan dilakukan melalui telepon. Biaya pemesanan yang dikeluarkan oleh
Kelompok Tani Rahayu hanya biaya telepon karena kopi diterima di gudang. Sehingga biaya-biaya lain dibebankan kepada pemasok dan termasuk harga beli kopi yang diterima oleh pemasok. Setiap pemesanan menghabiskan biaya kira-kira Rp. 8.250 untuk satu kali melakukan pemesanan (Lampiran 4).

\section{Biaya Penyimpanan}

Penyimpanan kopi dimaksudkan untuk mengantisipasi permintaan pasar masa tidak panen.Kopi disimpan dalam bentuk HS atau Greenbean bukan Cherry sehingga tidak terjadi kerusakan pada saat kopi disimpan hingga dikirim ke konsumen. Biaya-biaya penyimpanan yang dikeluarkan oleh Kelompok Tani Rahayu meliputi biaya administrasi gudang, biaya listrik masing-masing menghabiskan biaya dengan prosentase $1,5 \%$ dan $0,5 \%$. Sementara untuk biaya keamanan kelompok ini tidak menggunakannya, karena gudang penyimpanan tidak diawasi karena sejauh ini aman.

\section{Perhitungan EOQ (Economic Order Quantity)}

Perhitungan persediaan bahan baku dengan menggunakan model EOQ adalah untuk mengetahui sejauh mana efisiensi biaya persediaan yang diterapkan oleh Kelompok Tani Rahayu. Untuk mengetahui biaya persediaan yang efisien maka dilakukan perbandingan antara biaya persediaan yang dikeluarkan oleh kelompok tani atau biaya aktual dengan hasil perhitungan dengan menggunakan model EOQ. Berikut ini adalah perbandingan pengelolaan persediaan oleh kelompok tani dengan perhitungan EOQ 
Perbandingan Pengelolaan Aktual Kelompok Tani dengan Hasil Perhitungan EOQ .

\begin{tabular}{lcc}
\hline \multicolumn{1}{c}{ Keterangan } & $\begin{array}{c}\text { Aktual } \\
\text { Perusahaan }\end{array}$ & Model EOQ \\
\hline Jumlah Pesanan (Q) & $508 \mathrm{~kg}$ & $268 \mathrm{~kg}$ \\
Frekuensi Pemesanan (F) & $12 \mathrm{kali}$ & $23 \mathrm{kali}$ \\
Jangka Waktu antar tiap Pesanan (T) & 21 hari & 11 hari \\
Biaya Total Persediaan (TC) & Rp.454.600 & Rp.375.380 \\
Selisih biaya total persediaan & Rp. 79.220 (17,43\%) \\
Biaya Marjinal & \multicolumn{2}{c}{ Rp. 78.830 } \\
\hline
\end{tabular}

Berdasarkan Tabel di atas dapat dilihat perbedaan dan perbandingan antara hasil pengelolaan persediaan kopi menurut kelompok tani rahayu dengan perhitungan EOQ. Hasil perhitungan EOQ menyebutkan bahwa kuantitas pemesanan sebaiknya adalah 268 kilogram dengan 23kali pemesanan. Sementara kondisi aktual di kelompok tani adalah 508 dan 12 kali pemesanan. Meskipun frekuensi pemesanan menurut model EOQ lebih sering namun tetap lebih efisien karena perhitungan biaya total persediaan menunjukkan hal tersebut. Biaya total persediaan yang dikeluarkan perusahaan lebih besar sebesar $17,43 \%$ dari pada biaya total persediaan yang dihasilkan oleh perhitungan EOQ.

Sementara itu, rasio sensitivitas sebesar 1,21 sedangkan biaya persediaan yang optimal akan tercapai apabila rasio sensitivitasnya adalah 1 . Apabila rasio sensitivitasnya lebih besar dari 1 maka biaya persediaan yang dilakukan kelompok tani tidak optimal (Ma'arif dan Tanjung, 2003). Rasio sensitivitas 1,21 berarti lebih dari 1 berarti kelompok tani menanggung biaya marginal. Biaya Marjinal adalah biaya tambahan yang harus ditanggung oleh kelompok tani karena jumlah persediaan yang tidak optimal. Biaya marjinal atau biaya tambahan yang harus dikeluarkan oleh kelompok tani karena pengelolaan persediaan yang tidak optimal adalah sebesar Rp.78.830,-.

Persediaan Pengaman (Safety Stock) dan Titik Pemesanan Ulang (Reorder Point atau ROP)

Persediaan pengaman (safety stock) merupakan persediaan yang dicadangkan untuk mengantisipasi apabila suatu waktu perusahaan mengalami kekurangan bahan baku. Perhitungan persediaan pengaman (safety stock) ditentukan dengan pertimbangan tingkat layanan kepada pelanggan (level of approach).

Titik pemesanan kembali adalah jumlah persediaan yang menandai saat harus dilakukannya pemesanan bahan baku kembali sehingga kedatangan atau penerimaan bahan baku kembali tepat waktu. Titik pemesanan kembali menandakan bahwa pembelian bahan baku harus segera dilakukan untuk menggantikan persediaan bahan baku yang sebelumnya telah dipakai untuk proses produksi. 
Menurut hasil perhitungan persediaan pengaman (safety stock), jumlah persediaan pengaman adalah sebesar 93 kilogram sementara persediaan pengaman yang dilakukan perusahaan adalah sebesar 24 kilogram. Sehingga terjadi perbedaan biaya total yang dikeluarkan ketika persediaan pengaman dimasukkan. Biaya total dengan persediaan pengaman hasil perhitungan EOQ ditambah persediaan pengaman adalah sebesar Rp. 505.507 sedangkan hasil actual di perusahaan adalah sebesar Rp. 530.282 Selisih antara biaya total persediaan yang dikeluarkan oleh perusahaan dengan hasil perhitungan adalah sebesar $5 \%$

Titik Pemesanan Ulang (Reorder Point atau ROP) model EOQ dengan mempertimbangkan persediaan pengaman adalah pada saat kuantitas persediaan kopi sebanyak 239 kilogram.

\section{Analis is Sensitivitas dan Biaya Marjinal}

Untuk menghitung biaya marjinal maka dihitung terlebih dahulu rasio sensitivitas. Biaya marjinal digunakan untuk mengetahui tingkat efisiensi dari suatu persediaan yang terdapat di dalam Kelompok Tani Rahayu. Apabila rasio stensitivitasnya lebih besar dari 1 maka biaya persediaan tidak optimal, artinya perusahaan menanggung biaya marjinal. Rasio sensitivitas diperoleh dengan cara membandingkan biaya total persediaan yang dikeluarkan perusahaan dengan biaya total persediaan hasil perhitungan. Biaya marjinal diperoleh dengan cara rasio sensitivitas yang diperoleh dari perhitungan dikurangi rasio sensitivitas terendah yaitu 1 dan dikalikan dengan total biaya persediaan hasil perhitungan.

Rasio sensitivitas dan biaya marjinal yang dihasilkan terdiri dari analisis sensitivitas dan biaya marjinal untuk perhitungan EOQ, perhitungan EOQ dengan persediaan pengaman.

Rasio sensitivitas dan biaya marjinal

\begin{tabular}{lrcc}
\hline \multicolumn{2}{c}{ Keterangan } & Rasio Sensitivitas & Biaya Marjinal \\
\hline Perhitungan EOQ & & 1,21 & 78.830 \\
\hline $\begin{array}{l}\text { Perhitungan EOQ } \\
\text { menambahkan } \\
\text { pengaman }\end{array}$ & $\begin{array}{r}\text { dengan } \\
\text { persediaan }\end{array}$ & 1,05 & 25.279 \\
\hline
\end{tabular}

Berdasarkan tabel di atas dapat dilihat bahwa rasio sensitivitas dari seluruh perhitungan yang digunakan melebihi 1.Rasio sensitivitas yang melebihi 1 merupakan nilai yang menunjukkan bahwa persediaan yang diterapkan kelompok tani belum
efisien.Dengan kata lain kelompok tani menanggung biaya tambahan akibat tidak efisiennya pengelolaan persediaan. Biaya tambahan yang harus dikeluarkan oleh kelompok tani dalam hal ini disebut biaya marjinal. 


\section{Perbandingan Hasil Perhitungan Model Persediaan yang Digunakan}

Perbandingan hasil perhitungan model persediaan ini melihat model persediaan yang paling efektif dan efisien. Perbandingan yang dilakukan terdiri atas dua aspek. Aspek yang pertama adalah perbandingan aktual perusahaan dengan model persediaan tanpa menambahkan persediaan pengaman (safety stock). Aspek yang kedua adalah perbandingan aktual perusahaan dengan model persediaan yang menambahkan persediaan pengaman (safety stock). Perbandingan hasil perhitungan tersebut dapat dilihat pada tabel dibawah ini :

Perbandingan Hasil Perhitungan Model Persediaan Tanpa Persediaan Pengaman

\begin{tabular}{lcc}
\hline \multicolumn{1}{c}{ Keterangan } & Aktual Perusahaan & Model EOQ \\
\hline Jumlah Pesanan (Q) & $508 \mathrm{~kg}$ & $268 \mathrm{~kg}$ \\
\hline Frekuensi Pemesanan (F) & $12 \mathrm{kali}$ & $23 \mathrm{kali}$ \\
\hline $\begin{array}{l}\text { Jangka waktu antar tiap } \\
\text { pesanan (T) }\end{array}$ & 21 hari & 11 hari \\
\hline Biaya total persediaan (TC) & Rp.454.600 & Rp.375.380 \\
\hline
\end{tabular}

Berdasarkan tabel diatas dapat dilihat pengelolaan persediaan yang dilakukan Kelompok Tani Rahayu belum efisien. Berdasarkan kedua model yang dibandingkan dengan kondisi aktual di
Kelompok Tani Rahayu menunjukkan bahwa biaya total persediaan yang dikeluarkan masih lebih besar daripada hasil perhitungan model.

Perbandingan Hasil Perhitungan Model Persediaan dengan Persediaan Pengaman

\begin{tabular}{lcc}
\hline \multicolumn{1}{c}{ Keterangan } & $\begin{array}{c}\text { Aktual Perusahaan } \\
\text { dengan safety stock }\end{array}$ & $\begin{array}{c}\text { Model EOQ dengan safety } \\
\text { stock }\end{array}$ \\
\hline Jumlah Pesanan (Q) & $601 \mathrm{~kg}$ & $361 \mathrm{~kg}$ \\
\hline $\begin{array}{l}\text { Frekuensi Pemesanan (F) } \\
\text { Jangka waktu antar tiap } \\
\text { pesanan (T) }\end{array}$ & $12 \mathrm{kali}$ & $23 \mathrm{kali}$ \\
\hline Biaya total persediaan (TC) & Rp.530.282 & 11 hari \\
\hline
\end{tabular}




\section{Implikasi Terhadap Kelompok Tani Rahayu}

Menurut Ma'arif dan Tanjung (2003), jika keadaan memungkinkan boleh melakukan pesanan $10 \%$ di atas jumlah EOQ atau $10 \%$ di bawahnya. Tidak ada kendala bagi kelompok tani untuk menerapkan manajemen persediaan bahan baku dengan metode EOQ selama pasokan atau ketersediaan kopi selalu tersedia serta terdapat hubungan baik dengan pemasok. Model persediaan yang digunakan pada penelitian ini adalah model EOQ dan model pengembangan dari EOQ. Untuk mengetahui implikasi terhadap perusahaan dilakukan dengan cara yang sama yakni di atas dan di bawah $10 \%$. Hal tersebut dilakukan agar kondisinya seimbang sehingga sesuai untuk dibandingkan. Hasil perhitungan melakukan pesanan $10 \%$ di atas jumlah hasil perhitungan atau $10 \%$ di bawahnya dapat dilihat dari tabel di bawah ini.

Perhitungan EOQ dengan menambahkan persediaan pengaman

\begin{tabular}{lccc}
\hline \multicolumn{1}{c}{ Keterangan } & TC $(100 \%)$ & TC ( 90 \% ) & TC ( 110 \% ) \\
\hline Perhitungan EOQ & Rp.375.380 & Rp 377.507 & Rp 377.110 \\
\hline $\begin{array}{l}\text { Perhitungan EOQ dengan } \\
\text { menambahkan persediaan } \\
\text { pengaman }\end{array}$ & Rp.505.507 & Rp 507.707 & Rp 508.010 \\
\hline
\end{tabular}

Berdasarkan tabel di atas dapat dilihat implikasi pada kelompok tani dengan menerapkan di atas atau di bawah $10 \%$ dari hasil perhitungan model persediaan. Menurut perhitungan EOQ dan Perhitungan EOQ dengan menambahkan persediaan pengaman penurunan pesanan sebesar $10 \%$ justru meningkatkan biaya total persediaan. Melakukan pesanan kopi lebih kecil $10 \%$ pada model EOQ dan EOQ dengan persediaan pengaman akan meningkatkan biaya total sebesar $0,03 \%$ dan $0,04 \%$.

Dan perhitungan EOQ dan Perhitungan EOQ dengan menambahkan persediaan pengaman penambahan pesanan sebesar $10 \quad \% \quad$ justru meningkatkan biaya total persediaan.
Melakukan pesanan kopi lebih besar $10 \%$ pada model EOQ dan EOQ dengan persediaan pengaman akan meningkatkan biaya total sebesar $0,03 \%$ dan $0,05 \%$.

\section{Kesimpulan}

1) Kelompok Tani Rahayu memperoleh bahan baku kopi selain dari kelompok tani itu sendiri juga dari petani plasma, kelompokkelompok tani yang ada di pangalengan juga dari kelompok tani binaan dari bpk Dinuri. Kerjasama yang dilakukan melalui system kontrak per tahun dengan kesepakatan harga dan kualitas serta kuantitas kopi dicantumkan dalam kontrak. 
2) Perencanaan persediaan kebutuhan biji kopi sebagai bahan baku pembuatan kopi bubuk diterapkan kelompok tani rahayu disesuaikan dengan target produksi atau rencana penjualan produk. Pemesanan kopi dilakukan setiap bulannya sehingga dalam satu tahun terdapat 12 kali pemesanan. Namun jumlah pemesanan tidak selalu sama tergantung dari masa panen. Kuantitas pesanan kopi setiap satu kali pesanan 508 kilogram. Jangka waktu antar tiap pesanan adalah selama 21 hari.

3) Manajemen persediaan yang dilakukan oleh KelompokTani Rahayu belum efektif dan efisien. Hal ini dapat dibuktikan melalui perbandingan antara model persediaan yang digunakan dengan kondisi aktual yang terjadi di Kelompok Tani Rahayu. Model persediaan yang digunakan yakni EOQ.

\section{Saran}

Pengelolaan persediaan kopi di Kelompok Tani Rahayu harus lebih diperhatikan lagi tingkat efektifitas dan efisiensinya agar dapat memenuhi permintaan pasar.Ada baiknya dilakukan kerjasama dengan pemerintah dan kelompok-kelompok tani lainnya di luar pangalengan, ini disarankan agar saat permintaan akan kopi meningkat Kelompok Tani Rahayu dapat memenuhi permintaan konsumen.

Jika manajemen persediaan telah dipersiapkan sebelumnya maka
Kelompok Tani Tahayu tidak akan kekurangan persediaan kapanpun permintaan pasar meningkat.

\section{DAFTAR PUSTAKA}

AgusRistono. 2008.

ManajemenPersediaan. GrahaIlmu . Yogyakarta.

Anna Nagurney. 2006. Supply Chain Network Economics: Dynamic of Prices, Flows, and Profit. Melalui <http://www.wikipedia.co.id >

Christopher M. 1998. Logistics and supply Chains Management : Strategies for Reducing Cost and Improving Service. $2^{\text {nd }}$ Edition Financial Times and Prentice Hal. London.

EdyHerjanto. 2008. ManajemenOperasi. PT. Grasindo. Jakarta.

Gumbira Sai'd, A.Harizt Intan. 2001. Manajemen Agribisnis. Ghalia Indonesia. Jakarta.

Herman Darmawi. 2006. ManajemenRisiko. PT. BumiAksara. Jakarta.

Indrianti N., Tjen M. danToha I.S 2001. Model

PerencanaanKebutuhanBahand enganMempertimbangkanWaktu KadaluwarsaBahan.Jurnal Media Teknik No. 2 Tahun XXIII.Melalui<i-

lib.ugm.ac.id/jurna//download.p hp?dataId=3844> [18/01/2012]

JhonsonSitanggang. 2005. Analisis Persediaan GandumUntukMenin gkatkanKinerjaRantaiPasokandi PT ISM Bogasari Flour Mills. tesis.Program Pasca Sarjana. Institute Pertanian Bogor. Bogor. 
Marlon Sipahutar, 2012.

"KajianManajemenPersediaanKed elaisebagaiBahan Baku PembuatanKedelaiBubukInstan" Skripsi. SarjanaUniversitasPadjadjaran

Mubyarto. 1986. Pengantar Ekonomi Pertanian. LP3ES. Jakarta.

Mudrajat Kuncoro. 2003. Metode Riset untuk Bisnis dan Ekonomi: Bagaimana Meneliti dan Menulis Tesis ?. Jakarta. Erlangga.

M. Ali. 1999. Kamus Besar Bahasa Indonesia. Pustaka Amani. Jakarta.

Pedoman Program Pascasarjana. 2011. Penulisan Tesis/Disertasi dan Penulisan Artikel Ilmiah. Universitas Padjadjaran.Bandung.

RichardusEkoIndrajit, 2002, KonsepManajemen Supply Chain" Grasindo. Jakarta

Rusidi. 2002. Sinopsis Usulan Penelitian. Universitas Padjadjaran. Bandung.

Sandra Febriyanti, 2010. "DinamikaKelompokTaniHutanDal amUsahatani Perkebunan Kopi Rakyat" Skripsi. Program SarjanaUniversitasPadjadjaran

Sri Najiyati,IrdanDanarti,Ir. 2004. Kopi :Budidaya\&PenangananPasc apanen.PenebarSwadaya. Jakarta.

Sugiono. 2007. Metode Penelitian Kuantitatif Kualitatif $R \quad \& \quad D$. Cetakan II. Bandung Alfabeta.

Sunil Chopra and Peter Meindl. 2001. Supply Chain Management : Strategy, Planning, and Operation. Upper Saddle River. New Jersey. Prentice-Hall

Thomas L. Saaty. 1993. Pengambilan Keputusan Bagi Para Pemimpin (Proses Hirarki Analitik untuk Pengambilan Keputusan dalam Situasi yang Kompleks). PT Pustaka Binawan Pressindo. Jakarta. 